\title{
pH of exudate test in the physiological quality of crambe seeds
}

\section{Teste do pH do exsudato para avaliação da qualidade fisiológica de sementes de crambe}

\author{
Charline Zaratin Alves ${ }^{\mathrm{I}^{*}}$ Lennis Afraire Rodrigues ${ }^{\mathrm{I}}$ \\ Carlos Henrique Queiroz Rego' Josué Bispo da SilvaII
}

\section{ABSTRACT}

Crambe is a rapeseed with high oil content and can be used as a winter cover or as a source of raw material for the production of biodiesel, however espite the growing interest in the culture, research on the subject is still incipient, especially concerning the seed production and analysis technology. The purpose of this study is to evaluate the physiological quality of crambe seeds, 'FMS Brilhante'cultivar, by testing the $\mathrm{pH}$ of exudate. Five seed lots were submitted to the determination of water content and the tests of germination and vigor (first count, emergence and tetrazolium). In the conduction of $\mathrm{pH}$ exudate test, temperatures $\left(25\right.$ and $\left.30^{\circ} \mathrm{C}\right)$, and periods of seed imbibition in water $(15,30$ and 45 minutes) were tested. The experiment was conducted in a completely randomized manner, with four replicates, and the mean values were compared by the Tukey test at 5\% probability; Pearson correlation between the $\mathrm{pH}$ of the exudate and initial tests was also made. Testing the $\mathrm{pH}$ of exudate is promising for separating lots of crambe seeds and the following combinations of $25^{\circ} \mathrm{C} / 30$ minutes or $30^{\circ} \mathrm{C} / 45$ minutes can be used.

Key words: Crambe abyssinica Hochst, viability, vigor.

\section{RESUMO}

O crambe é uma brássica com alto teor de óleo, podendo ser utilizada como cobertura de inverno ou fonte de matéria prima para a produção de biodiesel, porém, apesar do crescente interesse pela cultura, as pesquisas ainda são incipientes, principalmente quanto à tecnologia de produção e análise de sementes. $O$ objetivo neste trabalho foi avaliar a qualidade fisiológica de sementes de crambe, cultivar 'FMS Brilhante', pelo teste do $\mathrm{pH}$ do exsudato. Para tanto, cinco lotes de sementes foram submetidos à determinação do teor de água e a testes de germinação e vigor (primeira contagem, emergência e tetrazólio). $\mathrm{Na}$ condução do teste do $\mathrm{pH}$ do exsudato, foram testadas as temperaturas constantes de 25 e $30^{\circ} \mathrm{C}$ e periodos de embebição das sementes em água de 15,30 e 45 minutos. $O$ experimento foi realizado no delineamento inteiramente casualizado com quatro repetições e as médias foram comparadas pelo teste de Tukey a 5\% de probabilidade; também foi feita a correlação de Pearson entre o $\mathrm{pH}$ do exsudato $e$ as avaliações iniciais. $O$ teste do $\mathrm{pH}$ do exsudato é promissor na separação de lotes de semente de crambe, podendo ser utilizadas as combinações $25^{\circ} \mathrm{C} / 30$ minutos ou $30^{\circ} \mathrm{C} / 45$ minutos.

Palavras-chave: Crambe abyssinica Hochst, viabilidade, vigor.

\section{INTRODUCTION}

Crambe (Crambe abyssinica Hochst) is a native rapeseed of the Mediterranean that is cultivated in some tropical and subtropical regions (CARNEIRO et al., 2009). It is considered a rustic plant that, until recently, was only used as forage in crop rotation and soil cover (VARISCO \& SIMONETTI, 2012). However, with the discovery of its high potential for vegetable oil production, research ended up directing its use as raw material for biodiesel (TRZECIAK et al., 2008), as the seeds present about $40 \%$ of oil (SOUZA et al., 2009). In addition, its cultivation is fully mechanized, using the same implements used in the cultivation of soybeans and corn, with only minor modifications (FERREIRA \& SILVA, 2011).

Researches involving crambe, especially regarding the quality control of seeds, are critical to the use of the culture and are justified by the potential of the species and lack of information regarding the physiological quality with which its seeds are

\footnotetext{
IDepartamento de Agronomia, Universidade Federal de Mato Grosso do Sul (UFMS), CP 112, 79560-000, Chapadão do Sul, MS, Brasil. E-mail: charline.alves@ufms.br. "Corresponding author.

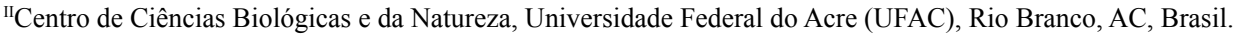


produced, especially in the state of Mato Grosso do Sul, where the production accounts for most of the national production (MASETTO et al., 2009). Only the germination test, most of the times, is not sufficient to detect differences in physiological potential of seeds, and the use of vigor testing becomes an important tool in seed analysis laboratories.

Until the moment, there is no universally accepted test to evaluate the vigor of seed of a determined species or a group of species. Some vigor tests are described in the literature for the crambe, such as first count (BRASIL, 2009), accelerated aging (CRUZ et al., 2013; AMARO et al., 2014) and controlled deterioration (SANTOS \& ROSSETTO, 2013); others, however, still need to be studied. The $\mathrm{pH}$ of exudate test is a vigor test considered promising in several species, enabling the determination of seed quality, being based on the permeability of membranes and solute leaching. When the seed imbibes water the release of sugars, organic acids and ions, including $\mathrm{H}^{+}$, takes place, which contributes to the acidification of the medium, resulting in a decrease in the $\mathrm{pH}$ of exudate, in which the most deteriorated seeds have a higher leaching and hence, exudates with more buffering capacity (PESKE \& AMARAL, 1984).

Many indicators solutions can be used to measure the $\mathrm{pH}$, one is phenolphthalein. The $\mathrm{pH}$ of the exudate with phenolphthalein test was used to determine the viability of soybean seeds by AMARAL $\&$ PESKE (1984). These authors considered as nonviable, seeds whose exudates presented weak pink color or colorless and concluded that 30 minutes of imbibition is the most efficient to estimate the germination of seeds.

Separating lots of soybean seeds, BARROS \& MARCOS FILHO (1990) reported that test to find the $\mathrm{pH}$ of exudate is effective and in the determination of feasibility; on top of being fast, presents a high reliability. The same was observed in corn seeds (SANTANA et al., 1998; CABRERA \& PESKE, 2002) and wheat (AMARAL \& PESKE, 2000).

Based on the efficiency of the $\mathrm{pH}$ of exudate test in some species, this study aims to adjust its methodology to crambe seeds, allowing to safely and quickly identify the vigor levels of lots.

\section{MATERIALS AND METHODS}

The experiment was conducted at the Seed Laboratório de Tecnologia da Universidade Federal de Mato Grosso do Sul, Campus of Chapadão do Sul using five lots of crambe seeds, 'FMS Brilhante' cultivar, subject to the determination of water content, germination and vigor for the initial lots characterization.

Determination of water content was performed using the oven method at $105 \pm 3^{\circ} \mathrm{C}$ for $24 \mathrm{~h}$, using two replicates with approximately $4 \mathrm{~g}$ per lot (BRASIL, 2009). For the germination test, four replicates of 100 seeds distributed in gerboxes on two sheets of germitest paper moistened with distilled water equivalent to 2.5 times the mass of the nonhydrated substrate. Boxes were kept in a germinator set at $20-30^{\circ} \mathrm{C}$ and the evaluations were made in the fourth and seventh days, used as primary root issue with $2 \mathrm{~mm}$ in length. Together with germination it was also performed the first germination count test, which consisted in recording the percentage of normal seedlings obtained on the fourth day after the test installation (BRASIL, 2009).

In emergence test, the seeds were sown in polystyrene trays with individual cells, containing the commercial substrate Plantmax ${ }^{\circledR}$, kept in a greenhouse with an automatic irrigation system. For each treatment, four replicates of 25 seeds were used, and the percentage of normal seedlings on the tenth day after planting was recorded.

Tetrazolium test was carried out with two replicates of 50 seeds preconditioned in germitest paper moistened with distilled water for $16 \mathrm{~h}$ at temperature of $25^{\circ} \mathrm{C}$; and after this period, the seeds were immersed in a $0,075 \%$ solution of $2,3,5$ triphenyl tetrazolium chloride for $8 \mathrm{~h}$ at $41^{\circ} \mathrm{C}$ in the dark. Subsequently, they were washed in running water and assessed individually and internally, verifying the intensity of color, and classifying it as viable (red color) and non-viable (colorless), according to the recommendation for Brassica spp. (BRASIL, 2009), with the result expressed as a percentage.

To conduct the test to find the $\mathrm{pH}$ of exudate two temperatures were tested $\left(25\right.$ and $\left.30^{\circ} \mathrm{C}\right)$, and three periods of seed imbibition (15, 30 and 45 minutes). Seeds were individually distributed in plastic trays and divided into unit cells submerged in $2 \mathrm{~mL}$ of distilled water, and subsequently subjected to the respective soaking periods and temperatures. Then, it was added one drop of phenolphthalein solution $(1 \mathrm{~g}$ of phenolphthalein dissolved in $100 \mathrm{~mL}$ of absolute ethanol and added to $100 \mathrm{~mL}$ of distilled and boiled water) and a drop of a sodium carbonate solution $(0,8 \mathrm{~g}$ of sodium carbonate in $1000 \mathrm{~mL}$ of distilled and boiled water) in each cell and the trays were agitated to promote mixing. The color change were observed in which pink color indicated the viable seed, while no color change indicated the no-viable seed being expressed in percentage. The experiment was 
conducted in a completely randomized manner with four replicates and the mean values were compared by Tukey test at $5 \%$ probability; Pearson correlation was also made between the initial assessments and the $\mathrm{pH}$ of exudate test.

\section{RESULTS AND DISCUSSION}

Seed water content was studied for both groups, with a maximum change of 0,6 percentage points (Table 1). Standardization of the seed moisture content is essential for the standardization of evaluations of vigor and achieving consistent results, since influences the occurrence of different metabolic processes that the seeds may be submitted (MARCOS FILHO, 2005).

In the germination test (Table 1) there was no significant difference in the percentage of normal seedlings, emphasizing that all lots were with germination higher than $60 \%$, the minimum value for the marketing crambe seed in Brazil (BRASIL, 2013). This is important since vigor tests should compare the performance of lots which follow the requirements established for commercialization and should have similar germination values (POWELL, 1986).

The tests of first count and tetrazolium ranked lots 1 and 2 as more vigorous and lots 3, 4 and 5 as less vigorous. Since the emergence test was more sensitive, lot 2 was identified as the more vigorous, lot 1 as intermediate vigor lots 3 and 4 , and lot 5 as the less vigorous (Table 1). The vigor tests identify lots that are likely to have lower or higher performance; however, they did not indicate that the lower performance may also not present adequate development in the field. If the environmental conditions are favorable, all lots will have opportunity to present good results, providing the establishment of the appropriate population on the field (SILVA \& VIEIRA, 2012).
The highest percentage of normal seedlings in the germination test when compared to the emergence test may be related to the greater availability of water, light and ideal temperature in the germinator during the germination test, ensuring a greater number of normal seedlings. When environmental conditions after sowing in the field deviate from the ideal conditions, it is expected that the percentage of seedling emergence is less than the germination determined in the laboratory.

The results obtained in the test for the $\mathrm{pH}$ of exudate found that, for all combinations of time and temperature tested, there was a separation of lots at different levels of vigor (Table 2). Overall, lot 2 showed the highest values in all combinations of $\mathrm{pH}$ of exudate testing (Table 2), except for $15^{\prime} / 25^{\circ} \mathrm{C}$ and $45^{\prime} / 25^{\circ} \mathrm{C}$, standing out as the most vigorous; and lot 5 as the least vigorous. All other lots behaved differently depending on the time and temperature used in the test.

In temperature of $25^{\circ} \mathrm{C}$, for the period of 15 minutes, lot 1 was rated as the most vigorous along with lot 2; at 30 minutes there was a distinction between lots 1 and 2 , and lot 1 was considered as intermediate vigor, matching statistically lots 3 and 4; with 45 minutes of soaking, it was not possible to separate lots 2, 3 and 4 in different levels of vigor (Table 2).

Similarly, at $30^{\circ} \mathrm{C}$ in the 15 minutes period, there was no difference of vigor between lots 1 and 2, or among batches 3, 4 and 5; already at 30 minutes, it was possible to separate lots 1 and 2 as the most vigorous, lots 3 and 4 as medium vigorous, and lot 5 as less vigorous; and, after 45 minutes of soaking, there was a classification of the lots into four levels of vigor, again being lot 2 considered as more vigorous and lot 5 as less vigorous (Table 2).

In table 3 it can be seen the Pearson correlation coefficients between the initial

Table 1 - Mean values for water content (WC), germination (G), first germination count (PCG), tetrazolium (TZ) and emergence (E) in five lots of crambe seeds.

\begin{tabular}{|c|c|c|c|c|c|}
\hline Lots & WC & G & $\mathrm{FGC}$ & $\mathrm{TZ}$ & $\mathrm{E}$ \\
\hline 1 & 8.9 & $89 a^{*}$ & $83 \mathrm{a}$ & $96 \mathrm{a}$ & $67 \mathrm{~b}$ \\
\hline 2 & 8.8 & $90 \mathrm{a}$ & $85 \mathrm{a}$ & $94 \mathrm{a}$ & $87 \mathrm{a}$ \\
\hline 3 & 8.5 & $84 \mathrm{a}$ & $75 \mathrm{~b}$ & $92 \mathrm{~b}$ & $69 \mathrm{~b}$ \\
\hline 4 & 9.1 & $85 \mathrm{a}$ & $70 \mathrm{~b}$ & $90 \mathrm{~b}$ & $74 \mathrm{~b}$ \\
\hline 5 & 8.7 & $86 \mathrm{a}$ & $68 \mathrm{~b}$ & $90 \mathrm{~b}$ & $48 \mathrm{c}$ \\
\hline $\mathrm{CV}(\%)$ & - & 6,6 & 7,0 & 5,1 & 8,3 \\
\hline
\end{tabular}

${ }^{*}$ mean values followed by the same letter in the column do not differ from one another according to the Tukey test at $5 \%$ probability. 
Table 2 - Mean values (\%) obtained from the $\mathrm{pH}$ of exudate test in five lots of crambe seeds in the soaking periods of 15,30 and 45 minutes at 25 and $30^{\circ} \mathrm{C}$.

\begin{tabular}{|c|c|c|c|c|c|c|}
\hline \multirow{2}{*}{ Lots } & \multicolumn{3}{|c|}{ 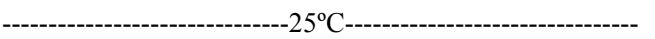 } & \multicolumn{3}{|c|}{ 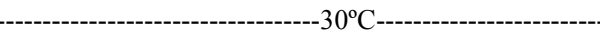 } \\
\hline & 15 , & 30 ' & $45^{\prime}$ & 15 , & 30 ' & $45^{\prime}$ \\
\hline 1 & $91 \mathrm{a}^{*}$ & $61 \mathrm{~b}$ & $65 \mathrm{~b}$ & $69 \mathrm{ab}$ & $78 \mathrm{a}$ & $63 \mathrm{~b}$ \\
\hline 2 & $84 \mathrm{a}$ & $93 \mathrm{a}$ & $78 \mathrm{ab}$ & $81 \mathrm{a}$ & $88 \mathrm{a}$ & $81 \mathrm{a}$ \\
\hline 3 & $49 \mathrm{bc}$ & $68 \mathrm{~b}$ & $84 \mathrm{a}$ & $56 \mathrm{bc}$ & $55 \mathrm{~b}$ & $57 \mathrm{bc}$ \\
\hline 4 & $63 \mathrm{~b}$ & $76 \mathrm{~b}$ & $78 \mathrm{ab}$ & $58 \mathrm{bc}$ & $49 \mathrm{~b}$ & $42 \mathrm{c}$ \\
\hline 5 & $43 \mathrm{c}$ & $42 \mathrm{c}$ & $38 \mathrm{c}$ & $44 \mathrm{c}$ & $9 \mathrm{c}$ & $18 \mathrm{~d}$ \\
\hline CV (\%) & 10.26 & 10.79 & 11.64 & 13.25 & 14.25 & 15.10 \\
\hline
\end{tabular}

${ }^{*}$ mean values followed by the same letter in the column do not differ from one another according to Tukey test at $5 \%$ probability.

assessments of the lots and the soaking period and temperature combinations in the $\mathrm{pH}$ of exudate test. To be deemed efficient, a vigor test shall provide a classification of lots at different levels, in proportion to the seedling emergence, as this is considered a parameter to indicate the effectiveness of tests to evaluate the physiological potential of seeds. Thus, the combinations that showed a significant correlation with emergence were 30 minutes at $25^{\circ} \mathrm{C}$ and 45 minutes at $30^{\circ} \mathrm{C}$. There was also a correlation of $\mathrm{pH}$ of exudate test with germination in all periods of soaking tested at $30^{\circ} \mathrm{C}$.

When evaluating rapid tests for Brassica juncea (L.) Coss. seeds, PUNIA et al. (2006) observed a significant correlation of the $\mathrm{pH}$ of exudate test with the emergence and germination when the seeds were subjected to the combination of a $25^{\circ} \mathrm{C} / 30$ minute soak, allowing to estimate quickly the viability of seeds. Similar results were found by PESKE \& AMARAL (1984) and BARROS \& MARCOS FILHO (1990) in soybean seeds and showed that the $\mathrm{pH}$ of exudate test, using the combination of $25^{\circ} \mathrm{C} / 30$ minutes was good in distinguishing viable from non-viable seeds.

In soybean and Guazuma ulmifolia Lam. seeds, SANTOS et al. (2011) and BARBOZA et al. (2014) reported that the $\mathrm{pH}$ of exudate test, at $25^{\circ} \mathrm{C} / 30$ minutes of soaking, was not effective in the separation of lots, differently from that observed by SANTANA et al. (1998) for maize and AMARAL \& PESKE (1984) for soybean. The correlation between the emergence test and the $\mathrm{pH}$ of exudate test shows a factor of considerable importance, since the seedling emergence are exposed to culture conditions which will find in the field, suffering direct interference environment, differently from the lab tests than in certain cases may mask the results as they are made in conditions that are controlled and appropriate for the seeds.

\section{CONCLUSION}

The $\mathrm{pH}$ exudates test is promising in the separation by vigor of crambe seeds lots, 'FMS

Table 3 - Pearson correlation coefficient (r) between the first count of germination (FCG), germination (G), emergence (E) and tetrazolium (TZ) and the $\mathrm{pH}$ of exudate test in soaking periods of 15,30 and 45 minutes at 25 and $30^{\circ} \mathrm{C}$, in five lots of crambe seeds.

\begin{tabular}{|c|c|c|c|c|c|c|}
\hline \multirow[b]{3}{*}{ FCG } & $15^{\prime}$ & $30^{\prime}$ & $45^{\prime}$ & $15^{\prime}$ & $30^{\prime}$ & $45^{\prime}$ \\
\hline & \multirow{2}{*}{\multicolumn{6}{|c|}{$0.84^{\mathrm{ns}} \quad 0.36^{\mathrm{ns}}$}} \\
\hline & & & $-0.07^{\mathrm{ns}}$ & $0.78^{\mathrm{ns}}$ & $0.64^{\mathrm{ns}}$ & $0.60^{\mathrm{ns}}$ \\
\hline G & $0.86^{\mathrm{ns}}$ & $0.58^{\mathrm{ns}}$ & $0.41^{\mathrm{ns}}$ & $0.92^{*}$ & $0.92^{*}$ & $0.92^{*}$ \\
\hline $\mathrm{E}$ & $0.62^{\text {ns }}$ & $0.99^{*}$ & $0.83^{\text {ns }}$ & $0.86^{\mathrm{ns}}$ & $0.85^{\mathrm{ns}}$ & $0.88^{*}$ \\
\hline $\mathrm{TZ}$ & $0.85^{\text {ns }}$ & $0.29^{\mathrm{ns}}$ & $0.24^{\mathrm{ns}}$ & $0.75^{\mathrm{ns}}$ & $0.81^{\mathrm{ns}}$ & $0.76^{\mathrm{ns}}$ \\
\hline
\end{tabular}

${ }^{*}$ significant at the $5 \%$ probability; ns not significant.

Ciência Rural, v.46, n.6, jun, 2016. 
Brilhante' cultivar, and the following combinations $25^{\circ} \mathrm{C} / 30 \mathrm{~min}$ or $30^{\circ} \mathrm{C} / 45$ minutes can be used.

\section{REFERENCES}

AMARAL, A.S.; PESKE, S.T. pH do exsudato para estimar, em 30 minutos, a viabilidade de sementes de soja. Revista Brasileira de Sementes, v.6, n.3, p.85-92, 1984. Available from: $<$ http://www.scielo. br/scielo.php?pid=S0101-31222002000100019\&script=sci_arttext $>$. Accessed: Nov. 18, 2014. doi: 10.1590/S0101-31222002000100019.

AMARAL, A.S.; PESKE, S.T. Testes para avaliação rápida da qualidade fisiológica de sementes de trigo. Revista Brasileira de Agrociência, v.6, n.1, p.12-15, 2000.

AMARO, H.T.R. et al. Teste de envelhecimento acelerado em sementes de crambe (Crambe abyssinica Hochst), cultivar 'FMS Brilhante'. Revista Ceres, v.61, n.2, p.202-208, 2014. Available from: <http://www.scielo.br/scielo.php?pid=S0034737X2014000200007\&script $=$ sci_arttext $>$. Accessed: Nov. 15, 2014. doi: 10.1590/S0034-737X2014000200007.

BARBOZA, V.R.S. et al. Potencial fisiológico de sementes de Guazuma ulmifolia Lam. através do teste do $\mathrm{pH}$ do exsudato. Enciclopédia Biosfera, v.10, n.18, p.2327-2335, 2014.

BARROS, A.S.R.; MARCOS FILHO, J. Testes para avaliação rápida da viabilidade de sementes de soja. Pesquisa Agropecuária Brasileira, v.25, n.10, p.1447-1459, 1990. Available from: <https:// seer.sct.embrapa.br/index.php/pab/article/viewFile/13666/7747>. Accessed: Apr. 14, 2014.

BRASIL. Ministério da Agricultura, Pecuária e Abastecimento. Regras para análise de sementes. Secretaria de Defesa Agropecuária. Brasília: Mapa/ACS, 2009. 395p.

BRASIL. Ministério da Agricultura, Pecuária e Abastecimento / Secretaria de Defesa Agropecuária. Portaria 16. Diário Oficial da República Federativa do Brasil, Brasília, 2013. Seção 1, p.2.

CABRERA, A.C.; PESKE, S.T. Teste do pH do exsudato para sementes de milho. Revista Brasileira de Sementes, v.24, n.1, p.134-140, 2002. Available from: <http://www.scielo.br/scielo. php? pid=S0101-31222002000100019\&script $=$ sci arttext $>$. Accessed: Nov. 10, 2014. doi: 10.1590/S0101-31222002000100019.

CARNEIRO, S.M.T.P.G. et al. Ocorrência de Alternaria brassicicola em crambe (Crambe abyssinica) no Estado do Paraná. Summa Phytopathologica, v.35, n.2, p.154, 2009. Available from: $<$ http://www.scielo.br/scielo.php?pid=S010054052009000200016\&script $=$ sci arttext $>$. Accessed: Nov. 08, 2014. doi: 10.1590/S0100-54052009000200016.

CRUZ, S.M. et al. Vigor tests for evaluation of crambe (Crambe abyssinica Hochst) seed quality. Journal of Seed Science, v.35, n.4, p.485-494, 2013. Available from: <http://www.scielo.br/ scielo.php?script $=$ sci arttext\&pid $=$ S2317-15372013000400010>. Accessed: Nov. 05, 2014. doi: 10.1590/S2317-15372013000400010.

FERREIRA, F.M.; SILVA, A.R.B. Produtividade de grãos e teor de óleo da cultura do crambe sob diferentes sistemas de manejo de solo em Rondonópolis, MT. Enciclopédia Biosfera, v.7, n.12, p.1-11, 2011. Available from: <http://www.conhecer.org. br/enciclop/2011a/agrarias/produtividade $\% 20 \mathrm{de} \% 20$ graos.pdf $>$. Accessed: Nov. 07, 2014.
MARCOS FILHO, J. Fisiologia de sementes de plantas cultivadas. Piracicaba, SP: FEALQ, 2005. 495p.

MASETTO, T.E. et al. Qualidade fisiológica e sanitária de sementes de crambe produzidas no estado do Mato Grosso do Sul. Revista Brasileira de Oleaginosas e Fibrosas, v.13, n.3, p.107$113,2009$.

PESKE, S.T.; AMARAL, A.S. Prediction of the germination of soybean seeds by measurement of the $\mathrm{pH}$ of seed exudates. Seed Science and Technology, v.14, n.1, p.151-156, 1986. Available from: $<$ http://agris.fao.org/agris-search/search.do?recordID=NL8601107>. Accessed: Nov. 17, 2014.

POWELL, A.A. Cell membranes and seed leachate conductivity in relation to the quality of seed for sowing. Journal of Seed Technology, v.10, n.2, p.81-100, 1986. Available from: <http:// www.jstor.org/stable/23432796?seq=1\#page_scan_tab_contents $>$. Accessed: Nov. 05, 2014.

PUNIA, R.C. et al. Exudate $\mathrm{pH}$ test: a quick and reliable predictor of seedling establishment in indian mustard [Brassica juncea (L.) Czern and Coss]. National Journal of Plant Improvement, v.8, n.2, p.103-105, 2006. Available from: $<$ http://www.cabdirect.org/ abstracts/20073117211.html;jsessionid=327F866E9D31B15DE49 5799DB2883DB6>. Accessed: Nov. 17, 2014.

SANTANA, D.C. et al. Teste do $\mathrm{pH}$ do exsudato-fenolftaleína para rápida definição sobre o destino de lotes de sementes de milho. Revista Brasileira de Sementes, v.20, n.1, p.160-166, 1998.

SANTOS, L.A.S.; ROSSETTO, C.A.V. Testes de vigor em sementes de Crambe abyssinica. Ciência Rural, v.43, n.2, p.233-238, 2013. Available from: <http://www.scielo.br/scielo.php?pid=S010384782013000200007\&script=sci arttext $>$. Accessed: Nov. 06, 2014. doi: 10.1590/S0103-84782013000200007.

SANTOS, J.F. et al. Avaliação do potencial fisiológico em lotes de sementes de soja. Revista Brasileira de Sementes, v.33, n.4, p.743-751, 2011. Available from: <http://www.scielo.br/ scielo.php?script $=$ sci_arttext\&pid=S0101-31222011000400016>. Accessed: Nov. 16, 2014 . doi: 10.1590/S010131222011000400016 .

SILVA, J.B.; VIEIRA, R.D. Deterioração controlada para avaliar o potencial fisiológico de sementes de beterraba. Horticultura Brasileira, v.30, n.3, p.379-384, 2012. Available from: <http:// www.scielo.br/pdf/hb/v30n3/04.pdf>. Accessed: Nov. 06, 2014.

SOUZA, A.D.V. et al. Caracterização química de sementes e tortas de pinhão-manso, nabo-forrageiro e crambe. Pesquisa Agropecuária Brasileira, v.44, n.10, p.1328-1335, 2009. Available from: <http://www.scielo.br/pdf/pab/v44n10/ v44n10a17.pdf $>$. Accessed: Nov. 17, 2014.

TRZECIAK, M.B. et al. Utilização de sementes de espécies oleaginosas para produção de biodiesel. Informativo Abrates, v.18, n.1/3, p.30-38, 2008. Available from: <http://www.abrates. org.br/images/stories/informativos/v18n123/artigo04.pdf $>$. Accessed: Nov. 23, 2014.

VARISCO, M.R.; SIMONETTI, A.P.M.M. Germinação de sementes de crambe sob influência de diferentes substratos e fotoperíodos. Acta Iguazu, v.1, n.2, p.36-46, 2012. Available from: <http://erevista.unioeste.br/index.php/actaiguazu/article/view/7035>. Accessed: Nov. 21, 2014. 